\title{
Honoring Professor Franz Stelzer: four decades of inspiring research
}

\author{
Wolfgang Kern ${ }^{1}$
}

Received: 10 May 2015/Accepted: 19 May 2015

(C) Springer-Verlag Wien 2015

Franz Stelzer was born in 1948 in Fürstenfeld, a city located in the eastern part of Styria (Austria). His interest in chemistry led him to study "Technical Chemistry" at the University of Technology in Graz (1966-1972). He completed his studies with a master thesis in the field of Physical Chemistry entitled "The adsorption behavior of gold" (supervised by Prof. H. Spath). In 1972, Franz Stelzer entered the field of Macromolecular Chemistry when beginning his Ph.D. thesis dealing with "Degradation of partially chlorinated polybutadiene by olefin metathesis". This thesis was conducted under the supervision of Prof. Klaus Hummel at the "Institute of Organic Chemistry and Technology of Organic Materials", and laid the foundation for the scientific career of Franz Stelzer. After receiving his doctoŕs degree (Dr. techn.) in 1975, Franz Stelzer continued his research work in the field of metathesis degradation of $\mathrm{C}=\mathrm{C}$ unsaturated polymers. In these years, he held the position of an Assistant Professor at the "Institute of Chemistry and Technology of Organic Materials" (the institute has now been divided into two new institutes) in the research group of his mentor, Prof. Klaus Hummel. In 1980, Franz Stelzer worked at the University of Durham (UK) in the group of Prof. W. J. Feast, as visiting scientist. Franz Stelzer received his Venia docendi for the subject "Chemical Technology of Organic Materials" in 1987. With a scholarship of the Max Kade foundation, Franz Stelzer stayed at the California Institute of Technology in Pasadena for 1 year (1988/1989). As a Visiting Associate in the research group of Prof. R. H.

Wolfgang Kern

wolfgang.kern@unileoben.ac.at

1 Montanuniversität Leoben, 8700 Leoben, Austria
Grubbs (Nobel prize laureate 2005), he worked on the synthesis and characterization of polyacetylene-polynorbornene-polyacetylene triblock copolymers [1].

Back at TU Graz in 1989, Franz Stelzer, now Associate Professor, rapidly set up a strong research group in the field of catalytic polymerization. A very important step in his research career was the Christian Doppler Laboratory (CDL) for Catalytic Polymerization, which he headed in the years 1991-1994. A particular highlight was the development of ring-opening polymerization reactions of oxanorbornene and norbornene derivatives in aqueous media [2]. In his research work, Franz Stelzer managed to combine the field of metathesis polymerization (aiming at the tailored architecture of functional macromolecules) with the field of organic electronics and other advanced applications of polymers. It should be stated that this field of research was entirely new in Austria at this time. With these new and advanced topics in the field of functional polymers, Franz Stelzer stimulated the Austrian polymer community on its way to the twenty-first century. Together with the research group of G. Leising at the Institute of Solid State Physics (TU Graz), an intensive research on electronic properties and applications of conjugated polymers, many of them prepared by the ring-opening polymerization (ROMP) of norbornene derivatives, was conducted in the years from 1991 on. Numerous studies were published e.g. on the preparation of conjugated polymers (in particular poly(arylenevinylene)s and polyacetylene-polynorbornene block copolymers) and their optical and electronic properties (e.g. [3]).

In 1996, the Spezialforschungsbereich (SFB) Elektroaktive Stoffe, a research cluster on electroactive materials, started at the TU Graz (needless to say, that Franz Stelzer was a leading person during the initiation and operation of this research cluster). During its runtime from 1996 to 2006, the 
SFB was a framework of inspiring fundamental research covering several scientific disciplines related to battery technology, solid oxide fuel cells, functional polymers, and polymer-based organic electronics, spanning over Graz University of Technology, University of Graz, and University of Leoben. Research in the group of Franz Stelzer concentrated on segmented conjugated polymers, and over the years a "toolbox" consisting of a number of methods in polymer preparation (e.g. ROMP, ADMET, Suzuki couplings), several precursor monomers (cycloolefins, conjugated oligomers, and substituted norbornenes) together with suitable processing methods has been developed. The new functional polymers found application in organic lightemitting devices (OLEDs) and even in photovoltaic cells (e.g. precursor PPV in hybrid solar cells). Selected highlights of research in this period were novel precursor routes to poly( $p$-phenylene-butadieneylene) [4], liquid crystalline conjugated copolymers [5], alternating diene metathesis polycondensation (ALTMET) [6], blue light-emitting OLEDs based on polynorbornenes with fluorene units in their side chain [7], blue-green emitting PPV derivatives for polymer LEDs [8] as well as ROMP-based photoresist materials [9] and optical recording materials [10]. Moreover, ROMP polymers were investigated (and patented) as dental restorative materials [11].

The next important steps in the career of Franz Stelzer were the appointment as head of the Institute of Chemistry and Technology of Organic Materials (ICTOS) at TU Graz (1998), and the appointment as full professor in 2001. In the following years, Franz Stelzer held several important positions at the TU Graz: Dean of the Faculty of Technical Chemistry, Process Technology, and Biotechnology (2004-2007) and Vice Rector for Research and Technology at TU Graz (2007-2011).

Although these official functions turned out to consume a large fraction of the time budget of Franz Stelzer, he continued his research activities together with his team at ICTOS. The successful research in the SFB significantly contributed to the initiation of several other research activities. Examples are the project cluster ISOTEC within the Austrian Nano Initiative (2005-2012) aiming at integrated organic sensors and optoelectronics, the Polymer Competence Center Leoben (PCCL; aiming at precompetitive industrial research in the field of polymer science and engineering) with ICTOS being a core research partner since 2002, the Austrian National Research network (NFN) on topic of interface controlled and functionalized organic films (2006-2013), and many more national and international research projects. To give examples for European research projects, Franz Stelzer was coordinator of the EU-RTD project "DENTALOPT" (FP-5), and participated e.g. in the projects "Flexonics" (FP-6 STREP; 2005-2008), "Sensic" (EUREKA; 2003-2006), and “BioSurf” (FP-7; 2009-2011).
More recent research activities (in the field of metathesis polymerization) of Franz Stelzer and his team are e.g. devoted to functional polynorbornenes with antimicrobial and fungicidal properties [12], highly stereoregular poly(azanorbornene)s [13], and applications of ROMPbased polymers as sensors [14].

The scientific work of Franz Stelzer now comprises more than 200 reviewed publications, 8 book chapters, 15 patents (many of them filed in several countries), and innumerable presentations at conferences and workshops. During his scientific career, he has supervised more than $75 \mathrm{Ph}$.D. theses, and four of his co-workers have successfully performed their habilitation (G. Trimmel, C. Slugovc, J. Sassmannshausen, and F. Wiesbrock). In recognition of his scientific work, Franz Stelzer has received medals of honor of the University of Plzeñ (Czech Republic) and the Technical University of Kosice (Slovakia), the Prof. A. Hoffman's Medal of the Association of Polish Electrical Engineers, and the Herman F. Mark Medal of the Austrian Research Institute for Chemistry and Technology (ofi). Furthermore, Franz Stelzer is an honorary doctor (Dr. h.c.) of the University of Plzeň.

During his career, Franz Stelzer has always stimulated and organized scientific collaborations on a national and international level, and many of his activities succeeded in bringing together researchers of different disciplines. The integrative activities of Franz Stelzer are mirrored e.g. by NAWI Graz, which has been recognized as an exemplary and successful cooperation between University of Graz and Graz University of Technology in the field of natural sciences, both covering education and research.

Another example of networking activity is the biannual conference "Austrian Polymer Days" founded by Franz Stelzer. This symposium started in the Styrian "Seggau Castle" in 1995 as a national platform for Austrian polymer scientists, and has become a well-recognized multinational conference since then, in 2015 bringing together researchers from Austria, Slovenia, and the Czech Republic. Franz Stelzer has been the Austrian representative in the committee of the European Polymer Federation (epf) and was president of the epf in the years 2008-2009. The European Polymer Congress was then held in Graz 2009, which further contributed to the international recognition of Austrian polymer research. Moreover, Franz Stelzer has been member of the International Advisory Committee of the "International Symposia on Olefin Metathesis" since 1987 (ISOM VII in Hull, UK), and we are glad to host ISOM XXI in Graz this year.

On behalf of the Austrian polymer community I would like to thank Franz Stelzer for his highly successful endeavors in science and education over all these years. His work has significantly contributed to the development and recognition of Austrian polymer science on an international level. 


\section{References}

1. Stelzer F, Grubbs RH, Leising G (1991) Polymer 32:1851

2. Zenkl E, Stelzer F (1992) J Mol Catal 76:1

3. Graupner W, Leising G, Fischer W, Stelzer F (1993) Synth Met 58:77

4. Winkler B, Tasch S, Leising G, Stelzer F (1997) Synth Met $84: 383$

5. Koltzenburg S, Wolff D, Stelzer F, Springer J, Nuyken O (1998) Macromolecules 31:9166

6. Demel S, Slugove C, Stelzer F, Fodor-Csorba K, Galli G (2003) Macromol Rapid Commun 24:636

7. Zaami N, Slugovc C, Pogantsch A, Stelzer F (2004) Macromol Chem Phys 205:523

8. Mahler KA, Schlick H, Saf R, Stelzer F, Meghdadi F, Pogantsch A, Leising G, Möller K-C, Besenhard JO (2004) Macromol Chem Phys 205:1840
9. Meyer U, Kern W, Hummel K, Stelzer F (1999) Eur Polym J 35:69

10. Schöfberger W, Zaami N, Mahler KA, Langer G, Jakopic G, Pogantsch A, Kern W, Stelzer F (2003) Macromol Chem Phys 204:779

11. Mozner N, Jocham D, Stelzer F, Rheinberger V (2000) Lowcontraction dental materials. European Patent 2000-250010

12. Kreutzwiesner E, Noormofidi N, Wiesbrock F, Kern W, Rametsteiner K, Stelzer F, Slugovc C (2010) J Polym Sci Part A Polym Chem 48:4504

13. Rossegger E, Olah L, Fischer R, Kaschnitz P, Varga O, Kallay M, Scheipl G, Stelzer F, Wiesbrock F (2012) Polym Chem 3:2760

14. Knall AC, Tscherner M, Noormofidi N, Pein A, Saf R, Mereiter K, Ribitsch V, Stelzer F, Slugovc C (2012) Analyst 137:563 